\title{
Isomerization of Glucose to Fructose in Hydrolysates from Lignocellulosic Biomass Using Hydrotalcite
}

\author{
David Steinbach $^{1, *(1)}$, Andreas Klier ${ }^{1}$, Andrea Kruse ${ }^{2}{ }^{\mathbb{D}}$, Jörg Sauer ${ }^{1}$, Stefan Wild ${ }^{1}$ \\ and Marina Zanker ${ }^{1}$ \\ 1 Karlsruhe Institute of Technology (KIT), Institute for Catalysis Research and Technology, \\ Hermann-von-Helmholtz-Platz 1, 76344 Eggenstein-Leopoldshafen, Germany; andreas.klier@me.com (A.K.); \\ j.sauer@kit.edu (J.S.); stefan.wild@kit.edu (S.W.); zankermarina@gmail.com (M.Z.) \\ 2 Institute of Agricultural Engineering, University of Hohenheim, Garbenstrasse 9, 70599 Stuttgart, Germany; \\ Andrea_Kruse@uni-hohenheim.de \\ * Correspondence: David.Steinbach@partner.kit.edu
}

Received: 29 April 2020; Accepted: 27 May 2020; Published: 28 May 2020

check for

\begin{abstract}
The isomerization of glucose-containing hydrolysates to fructose is a key step in the process from lignocellulosic biomass to the platform chemical hydroxymethylfurfural. We investigated the isomerization reaction of glucose to fructose in water catalyzed by hydrotalcite. Catalyst characterization was performed via IR, XRD, and SEM. Firstly, glucose solutions at $\mathrm{pH}$-neutral conditions were converted under variation of the temperature, residence time, and catalyst loading, whereby a maximum of $25 \mathrm{wt} . \%$ fructose yield was obtained at a $38 \mathrm{wt.} \%$ glucose conversion. Secondly, isomerization was performed at $\mathrm{pH}=2$ using glucose solutions as well as glucose-containing hydrolysates from lignocellulosic biomass. Under acidic conditions, the hydrotalcite loses its activity for isomerization. Consequently, it is unavoidable to neutralize the acidic hydrolysate before the isomerization step with an inexpensive base. As a neutralizing agent $\mathrm{NaOH}$ is preferred over $\mathrm{Ba}(\mathrm{OH})_{2}$, since higher fructose yields are achieved with $\mathrm{NaOH}$. Lastly, a pH-neutral hydrolysate from lignocellulose was subjected to isomerization, yielding $16 \mathrm{wt} . \%$ fructose at a $32 \mathrm{wt} . \%$ glucose conversion. This work targets the application of catalytic systems on real biomass-derived samples.
\end{abstract}

Keywords: glucose; fructose; aldose-ketose isomerization; pretreatment; hydrolyzate; lignocellulose; hydrotalcite; hydroxymethylfurfural; biorefinery; bioeconomy

\section{Introduction}

Producing platform chemicals from renewable lignocellulose, which is considered as a secondgeneration biomass, has grown into a central point of interest. This is due to the limited availability of fossil resources, coupled with the aim of reducing the carbon footprint of such products [1]. One example is the production of hydroxymethylfurfural (HMF), which is one of the most important bio-based building blocks, and can be converted into a variety of interesting chemicals [2]. HMF can be synthesized based on hexoses and their polymers, including lignocellulosic cellulose, which consists of glucose units. However, low yields from the direct conversion of glucose to HMF in aqueous media are reported [2]. A previous isomerization of glucose to fructose could help to overcome this obstacle, because under the same reaction conditions, HMF yields from fructose are higher than those from glucose [3].

The isomerization of glucose to fructose is carried out industrially with pH-neutral glucose solutions [4], which have a higher glucose concentration than process waters from the acid-catalyzed pretreatment of lignocellulose (hydrolysates). In addition, the hydrolysates are highly acidic and contain numerous by-products. Due to these different properties with regard to the $\mathrm{pH}$ value, 
by-products, and glucose concentration, a suitable isomerization catalyst for hydrolysates has to be experimentally investigated.

Glucose cannot be completely converted to fructose in a single step, because the thermodynamic equilibrium ratio between glucose to fructose at $25{ }^{\circ} \mathrm{C}$ is 54:46 [5]. At higher temperatures, the equilibrium shifts towards fructose, caused by the weak endothermicity of the reaction (standard reaction enthalpy of $2.8 \mathrm{~kJ} / \mathrm{mol}[5])$.

The conversion of glucose to fructose is an aldose-ketose isomerization, which can take place via two mechanistic pathways (see Figure 1). The first pathway is a keto-enol tautomerism, which is called a Lobry de Bruyn-van Ekenstein rearrangement. This rearrangement is catalyzed by Brønsted bases as a proton acceptor and takes place via the 1,2-endiol. In a second mechanistic scenario, a Lewis acid is used, which also abstracts a proton and an intramolecular hydrogen shift follows. This hydrogen shift was demonstrated in a study by Román-Leshkov and co-workers [6] using a Sn- $\beta$ zeolite as a Lewis acid. This zeolite also catalyzes the ring opening of glucose into the acyclic form of the sugar [7]. For the biochemical isomerization, an intramolecular hydrogen shift takes place too [8,9], so that the enzyme participates in the reaction in a similar way to a Lewis acid.

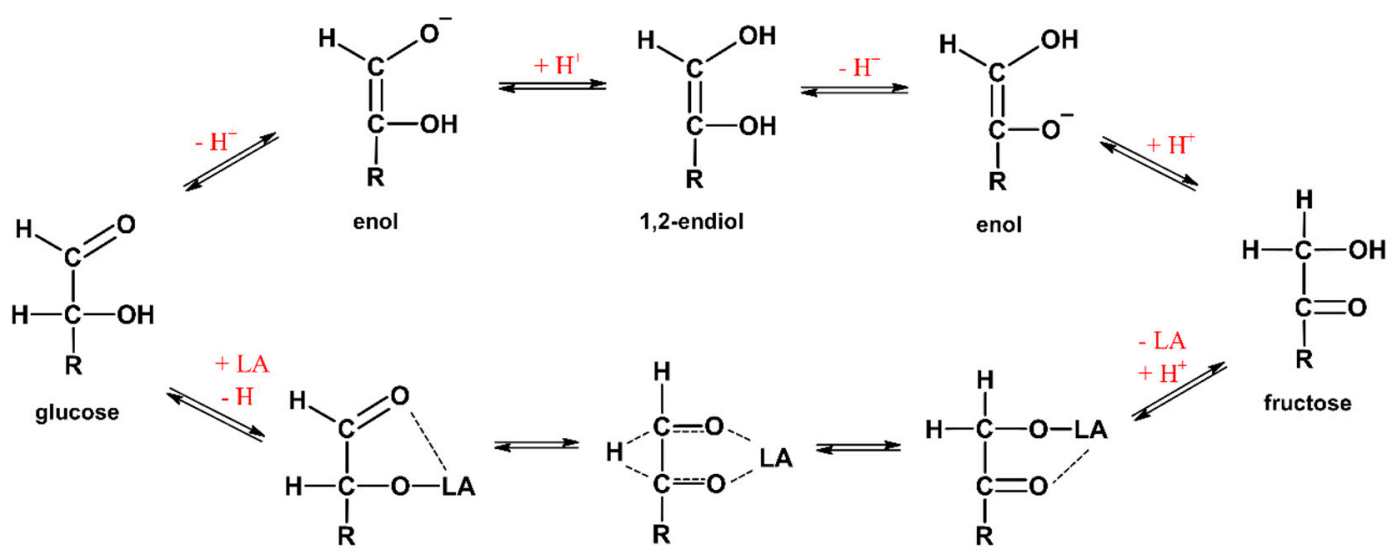

Figure 1. Mechanistic scenarios for isomerization of glucose to fructose [6], Brønsted base-catalyzed keto-enol tautomerism with hydrogen transfer (top) and Lewis acid-catalyzed intramolecular hydrogen shift (bottom), LA: Lewis acid.

Even without the presence of a catalyst, glucose isomerizes to fructose in hot high-pressure water [10]. However, in this case, the isomerization is a side reaction with low fructose selectivity, whereas other reactions predominate, like glucose defragmentation. In order to accelerate the glucose isomerization, various homogeneous and heterogeneous catalysts were investigated, which are summarized by Delidovich and Palkovits [11]. In all studies, glucose is used as a pure substance in aqueous solutions. To the best of our knowledge, the isomerization of a hydrolysate from the pretreatment of lignocellulose has not yet been investigated.

Heterogeneous catalysts are promising because they can be separated easily from the liquid phase for catalyst recycling. Both Brønsted bases and Lewis acids can be applied as a heterogeneous catalyst. Investigated heterogeneous Brønsted bases for isomerization include magnesium oxide, zirconium carbonate, hydrotalcite, attapulgite, zeolites modified with alkali and alkaline earth metals, microporous metal silicates, and basic resins [11,12]. An example for Lewis acid heterogeneous catalysts is the group of Sn- $\beta$ zeolites. The metal oxides of zirconium and titanium occupy an intermediate position, because they have both Lewis acid sites and base sites and thus act as bifunctional catalysts [13].

The isomerization results using hydrotalcites are summarized in Table 1. Hydrotalcites are magnesium-aluminum-hydroxycarbonates that occur as natural minerals or can be produced synthetically. The general formula is $\left[\mathrm{Mg}_{1-x} \mathrm{Al}_{x}(\mathrm{OH})_{2}\right]^{x+}[\mathrm{A}]^{x-} \cdot m \mathrm{H}_{2} \mathrm{O}$, where $x$ is the molar fraction of aluminum in the metal content and A symbolizes the anions, which are typically present as $\mathrm{CO}_{3}{ }^{2-}$ and $\mathrm{OH}^{-}$. Hydrotalcite forms layered structures with positively charged metal hydroxide layers and 
intermediate layers containing water and anions [14]. The anions in the interlayers are considered to be the active site for the isomerization [11]. The important aspect is whether the anions are present as $\mathrm{CO}_{3}{ }^{2-}$ or $\mathrm{OH}^{-}$, since $\mathrm{OH}^{-}$has a higher basicity and is therefore more catalytically active than $\mathrm{CO}_{3}{ }^{2-}[11,15]$. In addition, the accessibility of the catalytic anions plays a role in the isomerization, since glucose cannot penetrate into the intermediate layers of the hydrotalcite [11,16].

By calcining the hydrotalcite, first, water is released from the intermediate layers and, at higher temperatures, $\mathrm{CO}_{2}$ from the carbonate anions [15]. This creates a mixed $\mathrm{MgO}-\mathrm{Al}_{2} \mathrm{O}_{3}$ metal oxide with a large surface area [11,17]. However, the mixed metal oxides can incorporate anions into the intermediate layer, which again results in hydrotalcite, which is known as the memory effect $[15,17]$. Rehydration with water causes $\mathrm{OH}^{-}$anions, whereas $\mathrm{CO}_{2}$ contact causes the formation of $\mathrm{CO}_{3}{ }^{2-}$ anions in the intermediate layer [15]. The $\mathrm{OH}^{-}$layer in the intermediate layer is not stable in the presence of air and is converted into the carbonate form by $\mathrm{CO}_{2}$ absorption [16].

Table 1. Isomerization of glucose to fructose using hydrotalcite catalysts.

\begin{tabular}{cccccc}
\hline $\begin{array}{c}\text { Temperature } \\
{\left[{ }^{\circ} \mathbf{C}\right]}\end{array}$ & $\begin{array}{c}\text { Reaction Time } \\
{[\mathbf{m i n}]}\end{array}$ & $\begin{array}{c}\text { Glucose } \\
\text { Conversion [wt.\%] }\end{array}$ & $\begin{array}{c}\text { Fructose } \\
\text { Selectivity [wt.\%] }\end{array}$ & $\begin{array}{c}\text { Fructose } \\
\text { Yield [wt.\%] }\end{array}$ & Ref \\
\hline 90 & 60 & 28 & 78 & 22 & {$[15]$} \\
90 & 120 & 41 & 75 & 31 & {$[18]$} \\
110 & 180 & 34 & 89 & 30 & {$[16]$} \\
95 & $?$ & 42 & 60 & 25 & {$[19]$} \\
120 & 60 & 43 & 64 & 27 & {$[20]$} \\
100 & $?$ & 18 & 78 & 14 & {$[21]$} \\
90 & 120 & 61 & 83 & 50 & {$[22]$} \\
100 & 300 & 27 & 74 & 20 & {$[23]$} \\
100 & 300 & 61 & 66 & 42 & {$[24]$} \\
100 & 180 & 38 & 75 & 25 & {$[25]$} \\
120 & 240 & 36 & 56 & 30 & {$[26]$} \\
100 & 300 & 54 & & & {$[27]$} \\
\hline
\end{tabular}

Yu et al. [17] investigated the influence of hydrotalcite calcination and rehydration on glucose isomerization. The calcined catalyst provided a high glucose conversion with poor fructose selectivity, which is caused by the strongly basic sites of the mixed oxides [17]. On the other hand, the hydrotalcite rehydrated after calcination in water showed a high fructose selectivity, which is explained by weakly basic sites [17]. In a similar study by Delidovich and Palkovits [18], the hydrotalcite rehydrated in water gave the best fructose yields. A further work showed that targeted catalyst synthesis influences the basicity of the hydrotalcite [16]. A higher basicity not only leads to a higher glucose turnover but also to a higher fructose yield [16]. Additionally, hydrotalcite can be regenerated by burning off organic deposits and rehydrating in water [16].

No investigated heterogeneous catalyst enables a completely selective conversion of glucose into fructose. By-products are formed, which differ in species and yield, depending on the applied reaction conditions and used catalyst. Most studies report sugar epimer mannose as a by-product. Using hydrotalcite as catalyst, the reported by-products of isomerization are dihydroxyacetone, glycolaldehyde, lactic acid, and traces of glyceraldehyde [18]. The two C3 compounds dihydroxyacetone and glyceraldehyde are formed by adol splitting of fructose [28]. Glyceraldehyde can only be found in traces because it dehydrates to methylglyoxal, which is further converted into lactic acid in a benzylic acid rearrangement $[28,29]$. The $\mathrm{pH}$ value of the product liquid drops due to the produced lactic acid, which leads to the removal of $\mathrm{Mg}^{2+}$ ions from the hydrotalcite [18].

In this study, we investigated the isomerization reaction of glucose to fructose in water, using hydrotalcite as a catalyst. Firstly, glucose solutions at $\mathrm{pH}$-neutral conditions were converted under variation of the temperature, mass ratio of catalyst to glucose, and reaction time. Thereby, the optimal reaction conditions for glucose isomerization were determined. Catalyst characterization was performed via IR, XRD, and SEM. Secondly, isomerization was performed at $\mathrm{pH}$-acidic conditions, using 
glucose solutions as well as glucose-containing hydrolysates from lignocellulosic biomass. Thereby, the catalytic performance at $\mathrm{pH}$-acidic conditions was investigated. Last, a $\mathrm{pH}$-neutral hydrolysate was subjected to isomerization, in order to compare the isomerization of the lignocellulose-derived sample with glucose solutions.

\section{Materials and Methods}

\subsection{Obtaining a Glucose-Containing Hydrolysate from Lignocellulosic Biomass}

An acid-catalyzed pretreatment of lignocellulose was performed to obtain a glucose-containing hydrolysate. Beech wood chips (Joh. Sinnerbrink, Verl, Germany) or spruce wood chips (Hermann Keller, Achern, Germany) were used as educts. Diluted sulfuric acid was used as the catalyst to hydrolyze hemicelluloses and cellulose polymers in the lignocellulose structure to water-soluble sugar monomers.

A semi-continuous test rig was used for pretreatment, where the liquid phase was continuously exchanged [30]. This has the advantage that liberated water-soluble molecules like sugar monomers are removed from the hot reactor and thus largely protected from secondary reactions. Here, 180 and $200{ }^{\circ} \mathrm{C}$ were used as the reactor temperatures. The stainless-steel reactor has an internal volume of $100 \mathrm{~mL}$ and was loaded with $15 \mathrm{~g}$ of pre-dried wood chips as a fixed bed before the experiment. Demineralized water or dilute acid solution was continuously fed into the reactor at a volume flow of $15 \mathrm{~mL} / \mathrm{min}$. Demineralized water was pumped through the reactor during the heating phase. When the target temperature in the reactor was reached, the feed stream was switched to $0.05 \mathrm{~mol} / \mathrm{L}$ dilute sulfuric acid solution. The hydrolysate left the reactor continuously and was cooled in a heat exchanger. Hydrolysate sample was collected for about $1 \mathrm{~h}$ of acid-catalyzed lignocellulose hydrolysis and afterwards stored at $4{ }^{\circ} \mathrm{C}$ until further processing. The main organic components in the hydrolysate of spruce wood are $2.1 \mathrm{~g} / \mathrm{L}$ glucose, $0.91 \mathrm{~g} / \mathrm{L}$ hydroxymethylfurfural, $0.23 \mathrm{~g} / \mathrm{L}$ furfural, $0.05 \mathrm{~g} / \mathrm{L}$ levulinic acid, $0.03 \mathrm{~g} / \mathrm{L}$ formic acid, and $0.03 \mathrm{~g} / \mathrm{L}$ acetic acid. Other sugars like mannose, xylose, and fructose as well as short-chain organic compounds and high-molecular-weight substances, such as humines, are present in unknown quantities.

The hydrolysates were neutralized to $\mathrm{pH}=7$ by adding a strong base. This was done with constant stirring and $\mathrm{pH}$ measurement using a glass electrode. Concentrated sodium hydroxide or barium hydroxide solutions were used as bases. After neutralization, the solution was filtered through a $0.45-\mu$ m nylon membrane filter.

\subsection{Isomerization Experiments}

The hydrotalcite catalyst in powder form with the formula $\mathrm{Mg}_{6} \mathrm{Al}_{2}\left[(\mathrm{OH})_{16} \mid \mathrm{CO}_{3}\right] \cdot 4 \mathrm{H}_{2} \mathrm{O}$ was purchased (Sigma-Aldrich, St. Louis, MO, USA). The calcination was performed in a muffle furnace at $450{ }^{\circ} \mathrm{C}$ for $6 \mathrm{~h}$ with a continuous nitrogen purge. After the calcination, the catalyst was stored under nitrogen inert gas.

The isomerization was carried out in a glass apparatus. A defined amount of the calcinated catalyst and $40 \mathrm{~mL}$ of glucose solution or hydrolysate were placed in a 100-mL three-neck bottom flask with a magnetic stirrer. On top of the flask, a reflux cooler was installed, and the flask was heated in a preheated oil bath to the reaction temperature of $65-100{ }^{\circ} \mathrm{C}$ within about $20 \mathrm{~min}$, whereby the reaction temperature was measured in the solution. The gas phase in the glass apparatus was either air or inert gas via the continuous introduction of nitrogen into a side neck. After the reaction time of 0-120 min passed, the flask was removed from the oil bath and cooled by ambient air, while stirring continued. The content of the flask was then transferred quantitatively to a vacuum filtration unit and filtered through a $0.45-\mu \mathrm{m}$ nylon membrane. Then, $20 \mathrm{~mL}$ of deionized water were added to the vacuum filtration unit to wash the filter cake.

When an error bar is shown in the following diagrams, the isomerization experiments were carried out at least in triplicate, or otherwise as a single determination. The fructose yield after the 
isomerization of the hydrolysate was calculated based on the glucose in the hydrolysate, not including other hexoses.

\subsection{Analytics}

Characterization of the liquid samples after isomerization was performed with several HPLC methods. Preliminary filtration with $0.45-\mu \mathrm{m}$ GHP syringe filters (Pall, New York, NY, USA) was performed to remove high-molecular-weight products. Glucose, fructose, and mannose were separated at $35{ }^{\circ} \mathrm{C}$ in a Metrosep Carb 2 column (Metrohm, Filderstadt, Germany). An eluent with $0.1 \mathrm{~mol} / \mathrm{L}$ sodium hydroxide and $0.01 \mathrm{~mol} / \mathrm{L}$ sodium acetate was used with a flow rate of $0.5 \mathrm{~mL} / \mathrm{min}$. Sugars were quantified by an amperometric detector. As by-products of the isomerization reaction, short-chain aldehydes and organic acids as well as furan compounds were considered. However, we could not detect those compounds in any sample, if pure glucose solutions were subjected to isomerization. The furan compounds hydroxymethylfurfural, furfural, and methylfurfural were separated at $20{ }^{\circ} \mathrm{C}$ in a Lichrospher 100 RP-18 column (Merck, Darmstadt, Germany) and quantified by a UV detector at $290 \mathrm{~nm}$. Therefore, a water-acetonitrile eluent $(9: 1 \mathrm{v} / \mathrm{v})$ at a flow rate of $1.4 \mathrm{~mL} / \mathrm{min}$ was used. Short-chain aldehydes and organic acids like formic acid, acetic acid, lactic acid, and levulinic acid were separated with an Aminex HPX-87 H column (Biorad, Hercules, CA, USA) at a column temperature of $25{ }^{\circ} \mathrm{C}$. The eluent was $0.004 \mathrm{~mol} / \mathrm{L}$ sulfuric acid at a flow rate of $0.65 \mathrm{~mL} / \mathrm{min}$. Detection was performed by RI and DAD.

In the experimental runs at neutral $\mathrm{pH}$-conditions, glucose and fructose were also quantified by an enzymatic test kit (Boehringer Mannheim/R Biopharm, Darmstadt, Germany). Quantification was performed on a spectrophotometer CADAS 200 (Dr. Lange, Berlin, Germany).

The concentration of organic carbon (TOC) in the liquid samples was determined using a Dimatoc 2000 (Dimatec Analysentechnik, Essen, Germany) by applying the differential method. The sample was catalytically oxidized at $850^{\circ} \mathrm{C}$, whereby all carbon was converted into $\mathrm{CO}_{2}$, which was measured with an IR detector. By adding phosphoric acid to the sample at $160{ }^{\circ} \mathrm{C}$, only the inorganic carbon was converted to $\mathrm{CO}_{2}$ and subsequently measured.

The infrared spectra of dried hydrotalcite catalyst were recorded with an FT-IR spectrometer 660-IR (Varian, Palo Alto, USA) in transmittance mode for the wavenumbers of $4000-400 \mathrm{~cm}^{-1}$. The IR spectroscopy was carried out using $\mathrm{KBr}$ pellets, and the obtained spectra were normalized.

The surface structures of dried catalyst were investigated via scanning electron microscopy (SEM) in an LEO 982 Gemini (Carl Zeiss, Jena, Germany) equipped with a Schottky-type thermal field emission cathode, secondary electron detectors (Everhart-Thornley, inlens), and a backscattered electron detector.

For elemental analysis, the hydrotalcite catalyst was completely solved with concentrated acids $\left(\mathrm{HNO}_{3}, \mathrm{HCl}\right.$, and $\mathrm{HF}$ in a volume ratio of 6:2:1). The microwave digestion took place in a Mulitwave 3000 (Anton Paar, Graz, Austria), where the heating power was increased linearly to $500 \mathrm{~W}$ over $15 \mathrm{~min}$. Then, a temperature of $240^{\circ} \mathrm{C}$ was maintained for $60 \mathrm{~min}$. The analysis of the dissolved sample was carried out using optical emission spectrometry with inductively coupled plasma in the radial measurement mode on a 725 ICP-OES (Agilent, Santa Clara, CA, USA).

X-ray diffraction (XRD) provides information about the crystal structure of the dried catalyst. The measurement was carried out for $60 \mathrm{~min}$ on a X'Pert Pro (PANalytical, Almelo, Netherlands). A Bragg-Brentano arrangement with a copper anode and a nickel filter was used, the characteristic $\mathrm{X}$-ray radiation $\mathrm{K}_{\alpha}$ being used for the measurement.

\section{Results and Discussion}

\subsection{Glucose Isomerization under $p H-N e u t r a l$ Conditions}

The isomerization of glucose solutions with hydrotalcite has already been performed, for example, by Lecomte et al. [15]. Under the same reaction conditions, similar fructose yields were obtained 
(see Figure 2). However, the glucose conversion in this work (34 wt.\%) is higher than that found by Lecomte et al. [15] (27 wt.\%), which mainly results from the different methodology used for the calculation of the conversion. Lecomte et al. [15] subtracted out the glucose that was adsorbed on the catalyst (about $5 \mathrm{wt} . \%$ ). Additionally, they identified mannose and psicose as by-products, with a total yield of no more than $5 \mathrm{wt}$ \% [15]. In contrast, no mannose was detected in this study.

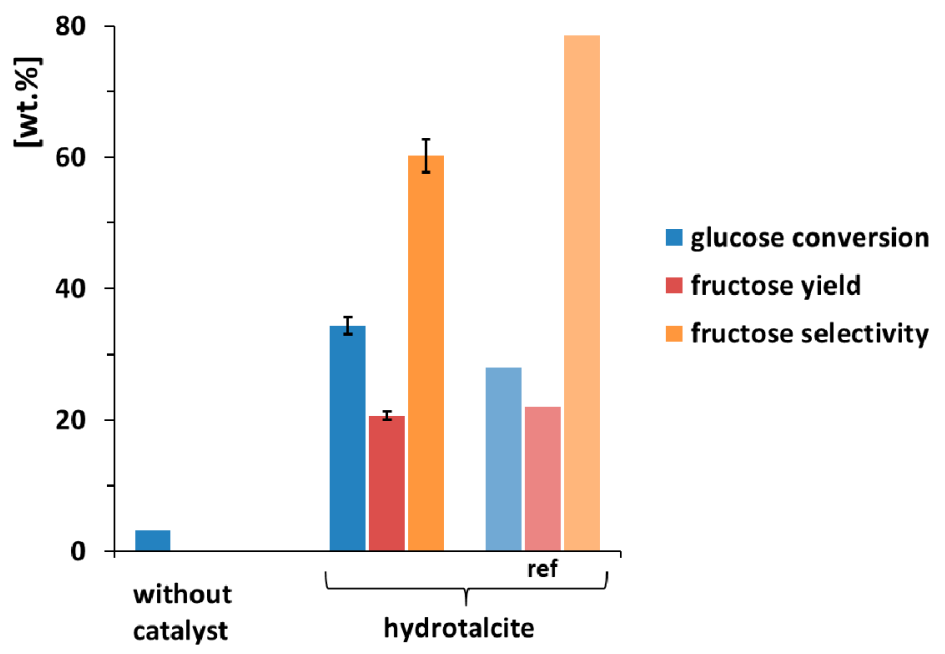

Figure 2. Glucose conversion and fructose yield using calcinated hydrotalcite, compared to Lecomte et al. [15] (ref), $c_{\text {glucose }}=100 \mathrm{~g} / \mathrm{L}, T=90^{\circ} \mathrm{C}, t=60 \mathrm{~min}$, air atmosphere, $m_{\text {catalyst }} / m_{\text {glucose }}=0.2$.

We used a different hydrotalcite catalyst than Lecomte et al. [15]. The $\mathrm{Mg} / \mathrm{Al}$ ratio has a strong effect on the catalytic properties for the isomerization reaction [24]. While the hydrotalcite used here has an $\mathrm{Mg} / \mathrm{Al}$ ratio of 3, Lecomte et al. [15] used a catalyst with an $\mathrm{Mg} / \mathrm{Al}$ ratio of 4.5. The basicity is highest at an $\mathrm{Mg} / \mathrm{Al}$ ratio of 3 and decreases at lower as well as larger ratios [31]. Too high basicity can lead to increased defragmentation reactions of the sugars to organic acids [17], which lowers the fructose selectivity. This was also shown by Moreau et al. [19], where an $\mathrm{Mg} / \mathrm{Al}$ ratio of 3 led to a lower fructose selectivity than an $\mathrm{Mg} / \mathrm{Al}$ ratio of 2.5 .

Because the glucose concentrations after pretreatment of lignocellulose will be much lower than $100 \mathrm{~g} / \mathrm{L}$, applied in the study of Lecomte et al. [15], parameter studies in this work were carried out with diluted glucose solutions. The variation in the isomerization temperature in the range from 65 to $100{ }^{\circ} \mathrm{C}$ shows that, under mild reaction conditions of $65^{\circ} \mathrm{C}$, glucose can be selectively converted into fructose with hydrotalcite (see Figure 3a). However, the yields are low (less than 10 wt.\%). Higher temperatures lead to increased glucose conversion, but the fructose selectivity decreases probably due to side reactions to unknown products, which lowers the fructose yield. However, no sugar defragmentation products (such as short-chain organic acids and aldehydes) or dehydration products (such as hydroxymethylfurfural and furfural) were detected via HPLC. Comparable studies with hydrotalcite found the sugar defragmentation products dihydroxyacetone, glycoladehyde, and lactic acid [16,18]. However, the applied residence times of $1.5-48 \mathrm{~h}$ were much longer than in this work. The concentrations of the defragmentation products are probably below the detection limit due to the shorter reaction time.

The glucose conversion increases with a longer reaction time (see Figure $3 b$ ). The fructose yield has a maximum of $25 \mathrm{wt}$ \% at about $60 \mathrm{~min}$. With longer reaction times, the fructose yield decreases again. Hence, the fructose formed could have reacted to secondary products. As a result, undesirable side reactions of both glucose and fructose occur. Subsequent reactions of fructose with longer residence times were also found by Souza et al. [32] during isomerization with $\mathrm{NaOH}$ as the catalyst. 


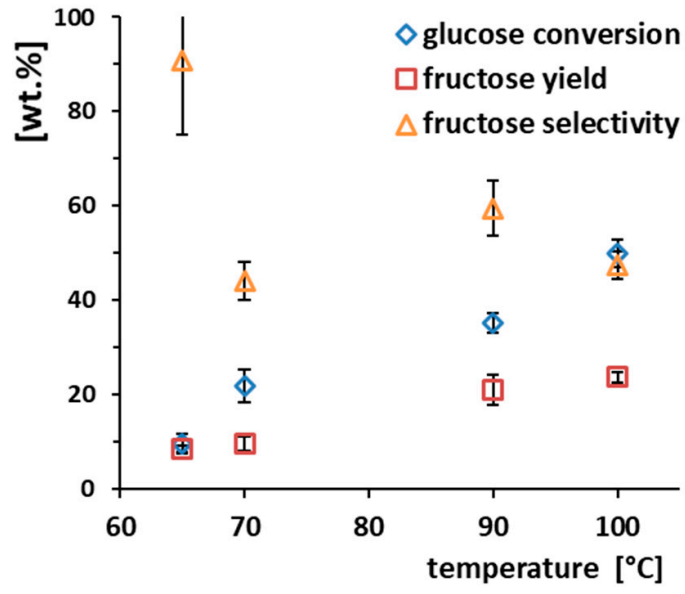

(a)

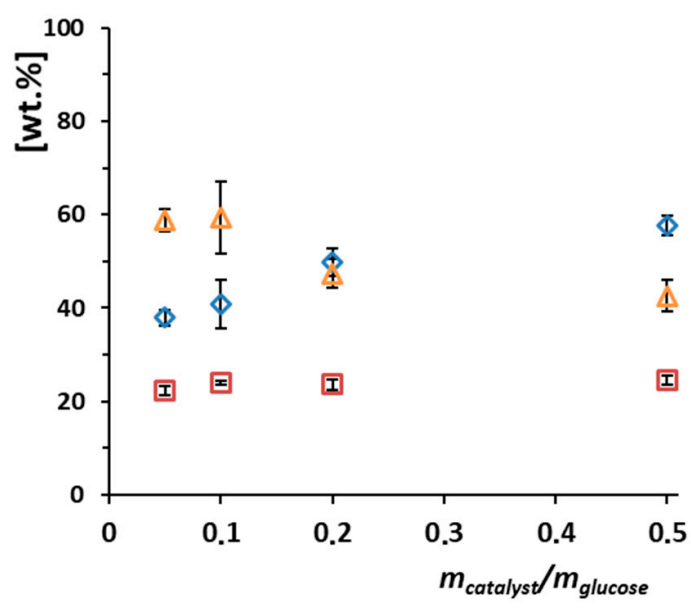

(c)

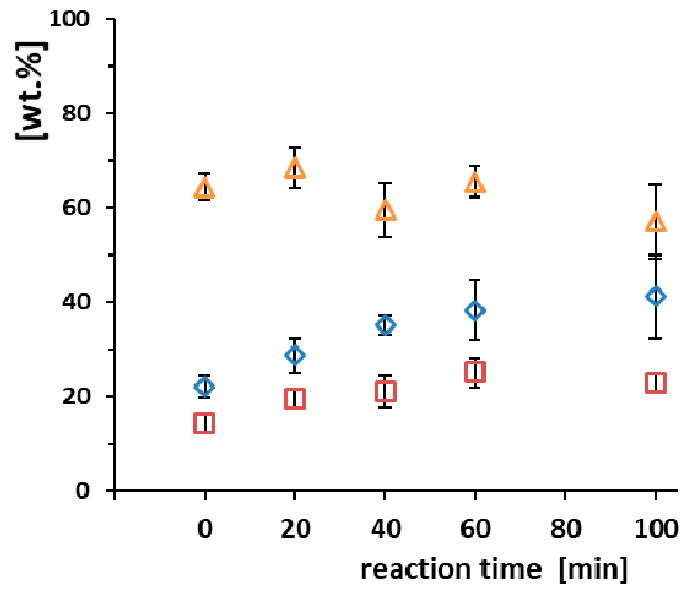

(b)

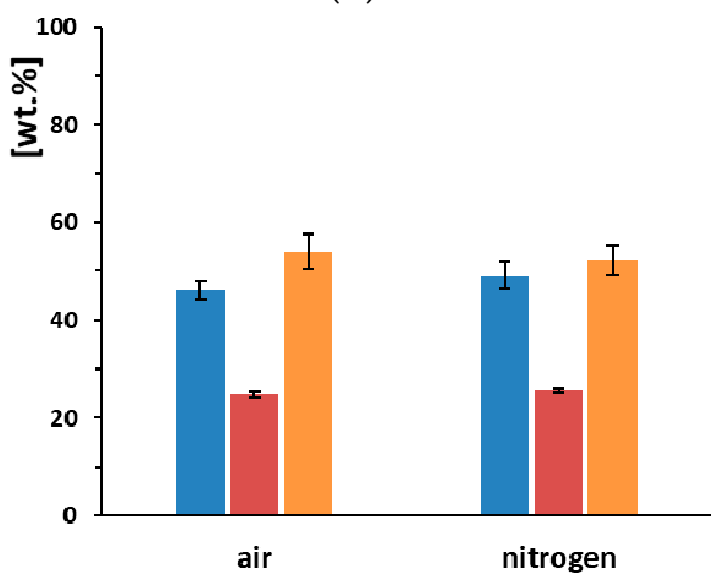

(d)

Figure 3. Glucose conversions and fructose yields using calcinated hydrotalcite with variation of (a) the temperature; (b) reaction time, for $t=0 \mathrm{~min}$, sample was heated up to the reaction temperature and then directly cooled down; and (c) mass ratio of catalyst to glucose at $T=100{ }^{\circ} \mathrm{C}$; and (d) gas atmosphere; always constant parameters: $c_{\text {glucose }}=5 \mathrm{~g} / \mathrm{L}, \mathrm{pH} \approx 7$; parameters (unless otherwise stated): air atmosphere, $T=90^{\circ} \mathrm{C}, t=40 \mathrm{~min}, m_{\text {catalyst }} / m_{\text {glucose }}=0.2$.

For the performed experiments, the mass ratio of catalyst to glucose had no influence on the fructose yield (see Figure 3c). Thus, the number of active catalyst sites might not kinetically limit the isomerization reaction. The increase in the glucose conversion with a higher amount of catalyst suggests that glucose could deposit on the surface of the catalyst.

Whether the gas phase consists of air or nitrogen has no influence on the glucose conversion or the fructose yield (see Figure 3d). Therefore, the oxidation products with ambient air play no role in the side reactions.

Because the glucose conversion is always much higher than the fructose yield, side reactions or deposition of glucose occur during isomerization. Figure 4 shows two carbon ratios to determine whether possible by-products are dissolved in the liquid phase. In the case of the reference point in Figure 4, no by-products are formed, and the fructose selectivity is $100 \mathrm{wt} . \%$. There are three model cases: (1) If the data point moves to the left in the diagram, by-products dissolved in water occur; (2) a shift of the data point on the bisector is caused by water-insoluble by-products; and (3) if the data point is below the bisector, this is due to measurement errors. The experimental data from the isomerization cannot be clearly assigned to any of these three cases. However, most runs are closer to the bisector, which is associated with water-insoluble by-products. Either this could be deposits 
on the catalyst, or soluble polymers are formed under reaction conditions, which precipitate before sample analysis. The latter soluble polymers were reported by Souza et al. [32] as a by-product of isomerization. On the other hand, Souzanchia et al. [21] reported the formation of undesired insoluble by-products, mainly humins, on the surface of the used hydrotacite catalysts.

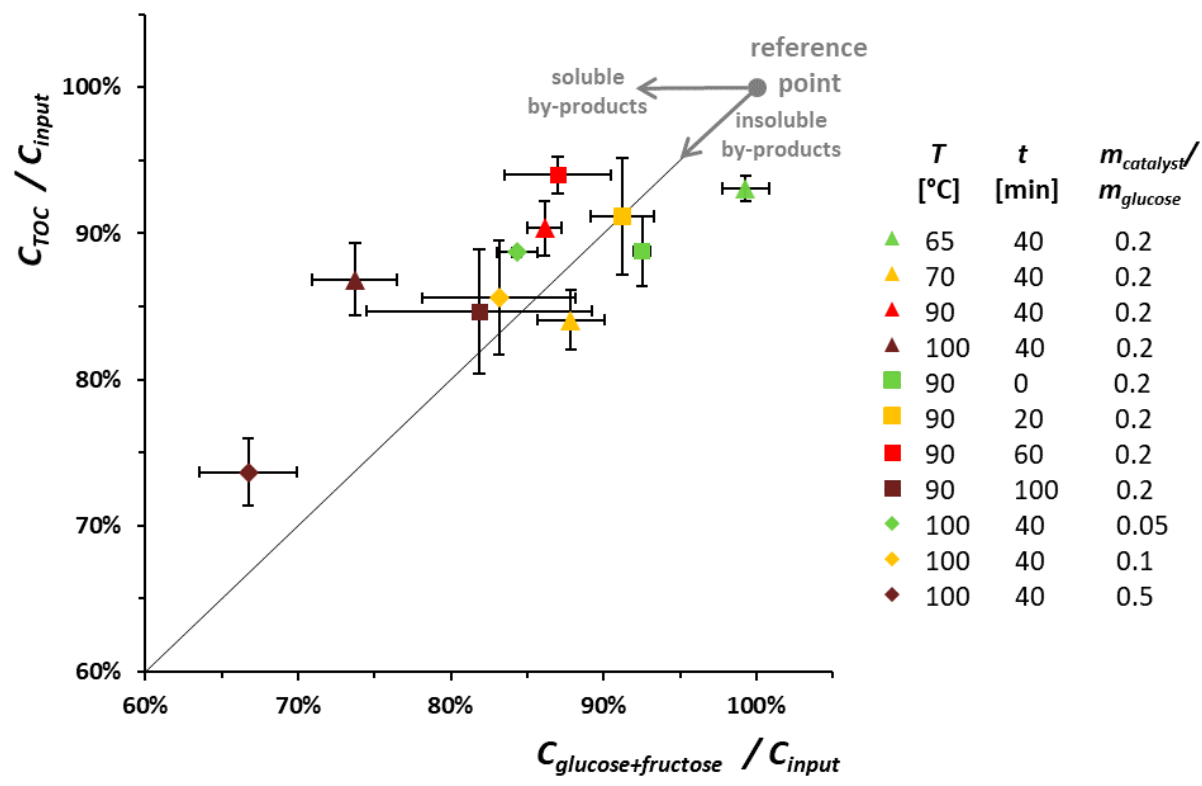

Figure 4. Carbon ratios for the isomerization of glucose with calcinated hydrotalcite; $Y$ axis: TOC (total organic carbon) of the product liquid to carbon input of the glucose solution $C_{T O C} / C_{\text {input }} ; \mathrm{X}$ axis: carbon of glucose and fructose in the product liquid to carbon input of the glucose solution $C_{\text {glucose }}+$ fructose $/ C_{\text {input }}$; reaction conditions: $c_{\text {glucose }}=5 \mathrm{~g} / \mathrm{L}, \mathrm{pH} \approx 7$, air atmosphere.

The IR spectra of the catalyst before and after the isomerization show only slight differences (see Figure 5a). Both spectra are dominated by a broad $\mathrm{O}-\mathrm{H}$ stretching vibration at $3450 \mathrm{~cm}^{-1}[33,34]$. The band at $1630 \mathrm{~cm}^{-1}$ is attributed to $\mathrm{O}-\mathrm{H}$ deformation vibrations [33]. The weak band at $760 \mathrm{~cm}^{-1}$ could be signals from Al-OH [33]. The bands in the range of $480-440 \mathrm{~cm}^{-1}$ are attributed to $\mathrm{Mg}-\mathrm{O}-\mathrm{Al}$ vibrations [33]. All other bands (1430, 1370, 760, $\left.660 \mathrm{~cm}^{-1}\right)$ originate from carbonates [29,33-35]. A precipitation of large amounts of organic matter during the isomerization on the catalyst surface is not detectable by IR spectroscopy, because no vibrations of organic compounds are found. For example, the spectra of the catalyst after isomerization show neither C-H valence vibrations at $2900 \mathrm{~cm}^{-1}$, nor $C=C$ valence vibrations of aromatics at $1600-1500 \mathrm{~cm}^{-1}$.

XRD was also used to characterize the catalyst (see Figure 5b). In the untreated hydrotalcite, two sharp symmetrical signals occur at $11.5^{\circ}$ and $23.2^{\circ}$ with high intensity. Weaker signals can be found at $34.8,39.8,46.7,60.7$, and $62.0^{\circ}$. The sharp XRD signals show that the untreated hydrotalcite catalyst has a crystalline structure and can be used to characterize the layered crystal structure [36,37]. The diffraction angles of the commercially available hydrotalcite used here are identical to other synthesized hydrotalcites $[16,17,29,33]$.

After calcining the hydrotalcite, all XRD signals of the layered crystal structure disappeared. So, the crystalline structure is lost and disordered $\mathrm{Mg}-\mathrm{Al}$ mixed oxides form $[17,29,38]$. After the isomerization, part of the crystalline order in the hydrotalcite returns, which can be seen from the XRD signals at low diffraction angles. This could be achieved by rehydration of the catalyst with water from the isomerization solution, whereby the layered crystal structure is restored by the "memory effect" $[17,29,38]$. 


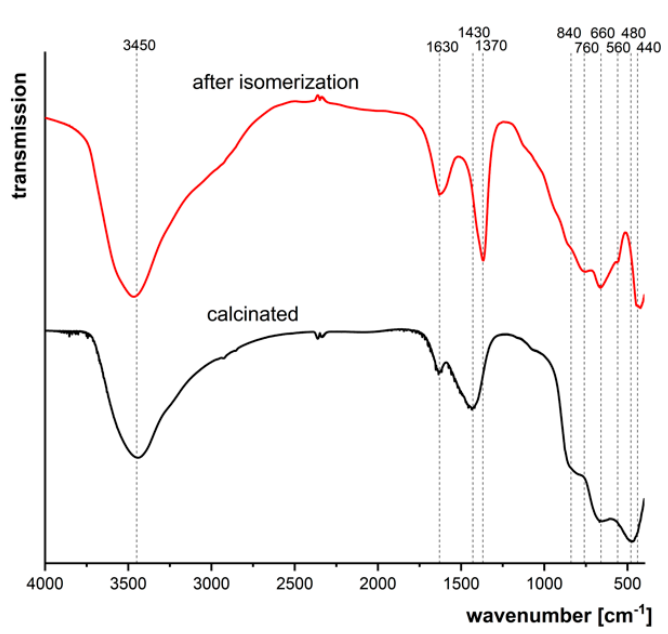

(a)

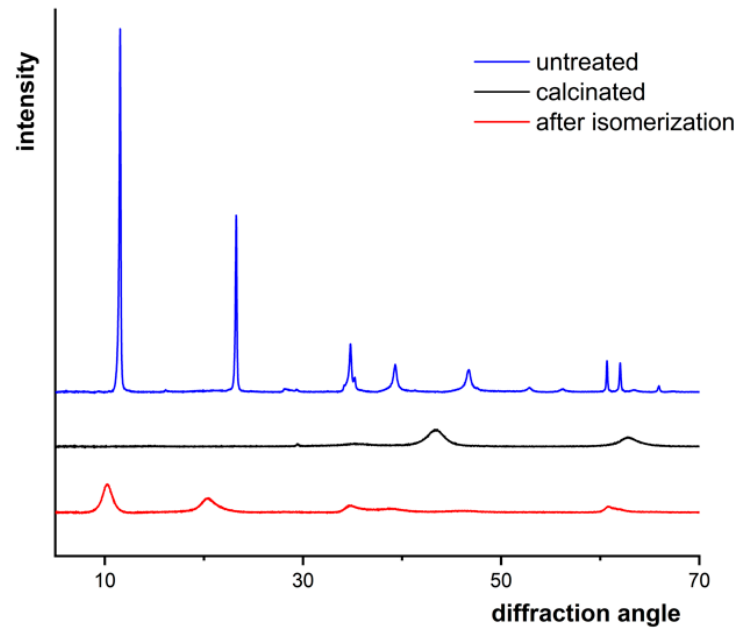

(b)

Figure 5. (a) IR spectra and (b) XRD pattern of hydrotalcite; reaction conditions: $c_{\text {glucose }}=5 \mathrm{~g} / \mathrm{L}, \mathrm{pH} \approx 7$, air atmosphere, $T=100{ }^{\circ} \mathrm{C}, t=40 \mathrm{~min}, m_{\text {catalyst }} / m_{\text {glucose }}=0.2$.

\subsection{Glucose Isomerization under $\mathrm{pH}$-Acidic Conditions}

By now, isomerization with hydrotalcite has only been investigated under $\mathrm{pH}$-neutral reaction conditions. However, the hydrolysate from the acid-catalyzed hydrolysis of lignocellulose is produced with an acidic $\mathrm{pH}$ value. Therefore, whether the hydrotalcite catalyzes the isomerization even under acidic conditions was investigated here. As can be seen in Figure 6, the glucose conversion drops sharply, if the $\mathrm{pH}$ value is decreased. This effect can be compensated by a larger mass ratio of catalyst to glucose.

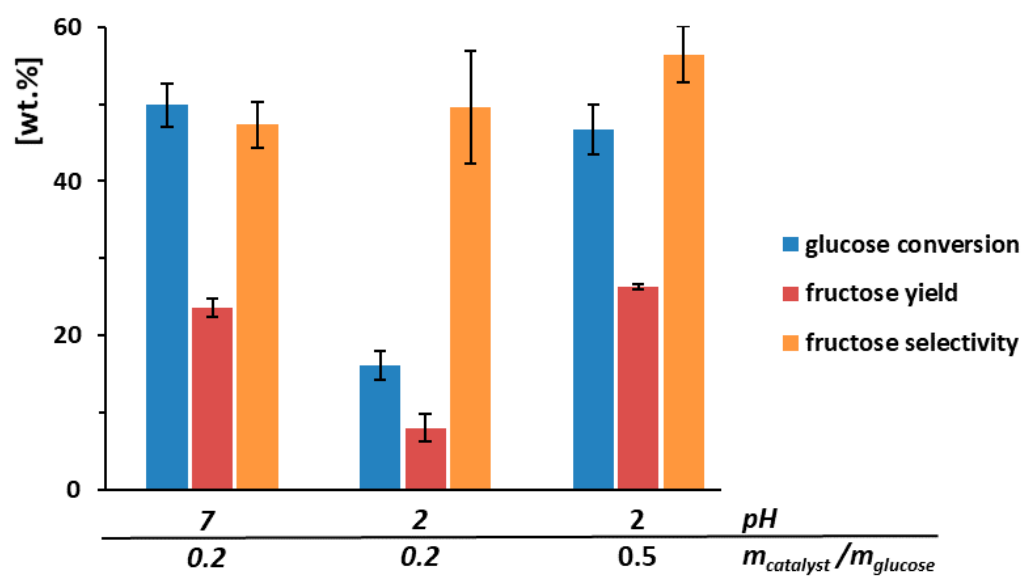

Figure 6. Glucose conversions and fructose yields with calcinated hydrotalcite with variation of the $\mathrm{pH}$ value by adding sulfuric acid, constant parameters $c_{\text {glucose }}=5 \mathrm{~g} / \mathrm{L}$, air atmosphere, $\mathrm{T}=100{ }^{\circ} \mathrm{C}$, $t=40 \mathrm{~min}$.

In addition, the dissolved metal ions in the product liquid were analyzed. During the isomerization, especially, magnesium ions are released from the catalyst. For example, $3.2 \mathrm{wt} . \%$ of the magnesium bound in the hydrotalcite goes into solution, in the run shown in Figure 6 with $m_{\text {catalyst }} / m_{\text {glucose }}=0.5$. In contrast, aluminum remains almost completely in the solid.

Under acidic $\mathrm{pH}$ conditions, hydrotalcite loses its activity for isomerization, which can be concluded from the decreased glucose conversion at $\mathrm{pH}=2$. The anions in the hydrotalcite solid structure are $\mathrm{OH}^{-}$ions after calcination and subsequent suspension in water [15]. These hydroxides 
are neutralized with the hydronium ions of sulfuric acid. This also makes the metal cations partially water soluble.

After the isomerization under acidic $\mathrm{pH}$ conditions, a clear change in the catalyst morphology is visible (see Figure 7). The catalyst appears to have partially dissolved and re-agglomerated into new particles of different morphology. The particles after the isomerization reaction are much larger than the particles of the calcinated catalyst before the start of the reaction.

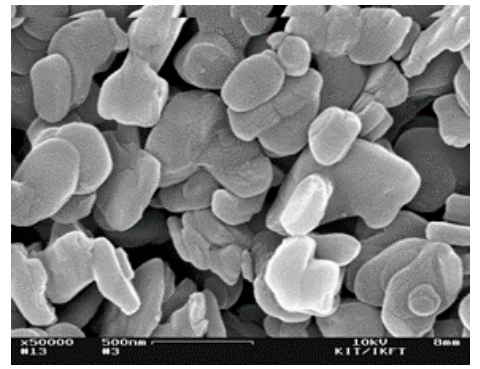

(a)

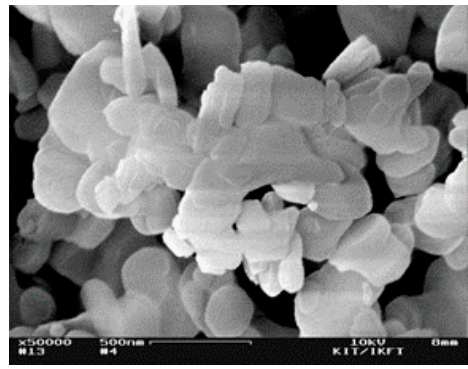

(b)

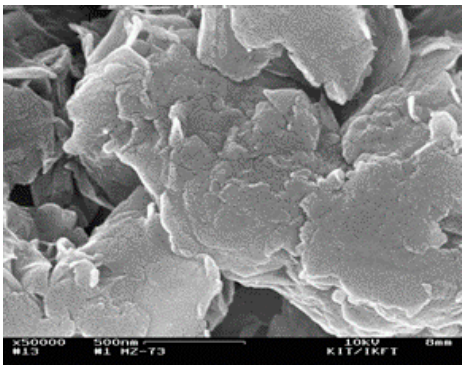

(c)

Figure 7. SEM images of the catalyst hydrotalcite in 50,000 $\times$ (a) before calcination, (b) calcinated and (c) after isomerization; reaction conditions: $T=100{ }^{\circ} \mathrm{C}, t=40 \mathrm{~min}, \mathrm{pH}=2$, air atmosphere, $m_{\text {catalyst }} / m_{\text {glucose }}=0.2$.

\subsection{Isomerization of Hydrolysate from Lignocellulose without Previous Neutralization}

If the acidic hydrolysate is exposed to the typical reaction conditions $\left(100{ }^{\circ} \mathrm{C}, 60 \mathrm{~min}\right)$ of the isomerization without the addition of hydrotalcite catalyst, no fructose is produced but almost $60 \mathrm{wt} . \%$ of the dissolved glucose is converted (see Figure 8). This shows that the organic compounds in the hydrolysate are very reactive in a $\mathrm{pH}$-acidic medium.

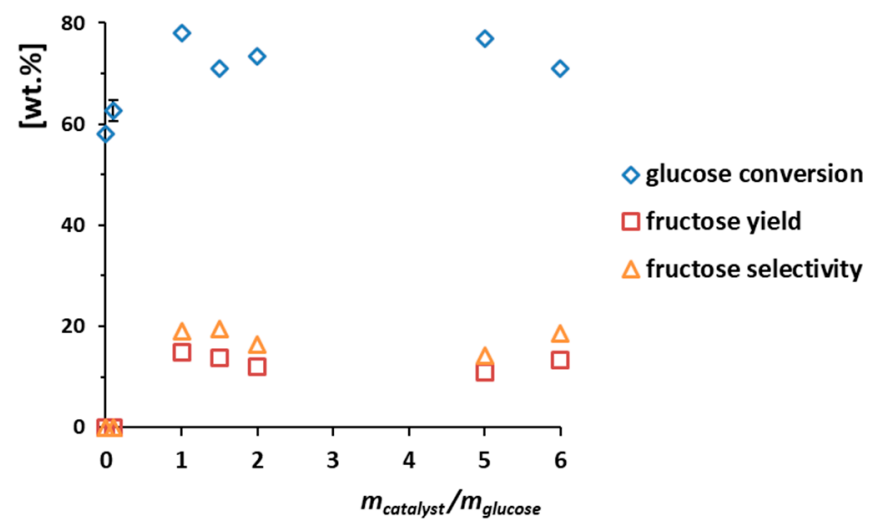

Figure 8. Glucose conversions and fructose yields of the calcinated hydrolysate from lignocellulose with a varying mass ratio of hydrotalcite catalyst to glucose; pretreatment parameters: beech wood, $T=180{ }^{\circ} \mathrm{C}, 0.05 \mathrm{~mol} / \mathrm{L} \mathrm{H}_{2} \mathrm{SO}_{4}$; isomerization parameters: $c_{\text {glucose }}=2.5 \mathrm{~g} / \mathrm{L}$, air atmosphere, $T=100{ }^{\circ} \mathrm{C}$, $t=60 \mathrm{~min}, \mathrm{pH}=1.3$.

When hydrotalcite is added in a catalyst/glucose ratio of 0.1 , no fructose is formed. In contrast, in the case of $\mathrm{pH}$-neutral glucose solutions, this catalyst loading was sufficient for fructose formation (see Figure 3c). Presumably, the catalytic active $\mathrm{OH}^{--}$ions in the hydrotalcite structure are neutralized by the sulfuric acid from the hydrolysate, as discussed in the previous chapter. The alkaline structure of the catalyst is lost, and the isomerization can no longer be catalyzed. This neutralization effect of the catalyst can be compensated by offering hydrotalcite in excess. However, using the isomerization catalyst as a neutralizing agent is not useful. Rather, the hydrolysate should be neutralized before the isomerization by an inexpensive base. 
Fructose is formed at a mass ratio of catalyst to glucose of 1 (see Figure 8). Even if this ratio is increased further, the fructose yield remains relatively constant at around 11-15 wt.\%. In general, these fructose yields of the hydrolysate are lower than the results with glucose solutions. In addition, the glucose turnover in the hydrolysate is much higher compared to a glucose solution.

\subsection{Isomerization of Hydrolysate from Lignocellulose after Previous Neutralization}

The two Brønsted bases $\mathrm{NaOH}$ and $\mathrm{Ba}(\mathrm{OH})_{2}$ were used to neutralize the hydrolysate from the sulfuric acid-catalyzed pretreatment of lignocellulose. When the $\mathrm{pH}$ was adjusted to 7 , the hydrolysate changed color from light brown to dark brown for both neutralizing agents. While the neutralization product $\mathrm{Na}_{2} \mathrm{SO}_{4}$ is highly water soluble, $\mathrm{BaSO}_{4}$ is almost insoluble $(2.3 \mathrm{mg} / \mathrm{L}$ [39]). Therefore, a precipitate is formed in the hydrolysate immediately after addition of $\mathrm{Ba}(\mathrm{OH})_{2}$. This difference in solubility and its effect on the process was the reason to use $\mathrm{Ba}(\mathrm{OH})_{2}$ as well as $\mathrm{NaOH}$.

The organic compounds remain largely dissolved in both neutralization variants. The analysis of the carbon concentration before and after neutralization shows a recovery of $91.7 \%$ for $\mathrm{NaOH}$ and $97.6 \%$ for $\mathrm{Ba}(\mathrm{OH})_{2}$. In addition, the concentrations of the measured by-products from acid-catalyzed pretreatment of lignocellulose (hydroxymethylfurfural, furfural, levulinic acid, formic acid, and acetic acid) were identical before and after the neutralization step. The solid precipitate of the $\mathrm{Ba}(\mathrm{OH})_{2}$ neutralization was examined via IR spectroscopy and shows agreement with the typical IR bands of $\mathrm{BaSO}_{4}$, while typical bands of organic compounds are not dominant (data not shown). So, if a salt is precipitated by the neutralization, no larger amounts of organic matter adsorb on it or co-precipitate.

No measurable fructose yields could be achieved with neutralized hydrolysate, when a hydrotalcitecatalyzed isomerization at mild reaction conditions of $60^{\circ} \mathrm{C}$ and $40 \mathrm{~min}$ was performed. However, fructose was obtained if the temperature was increased to $100{ }^{\circ} \mathrm{C}$ (see Figure 9). The mass ratio of catalyst to glucose in the examined range of 0.2 to 0.5 had no strong influence on the isomerization (see Figure 9b). If isomerization took place under inert gas, the fructose yield seemed higher than with ambient air (see Figure 9c). When the hydrolysate was neutralized with $\mathrm{NaOH}$ before the isomerization step, a much higher fructose yield could be achieved, compared to neutralization with $\mathrm{Ba}(\mathrm{OH})_{2}$ (see Figure 9a). Using $\mathrm{NaOH}$, the formed sodium sulfate salts remain solved in the isomerization step, whereas barium sulfate precipitates and is therefore not present in the isomerization step. The presence either of the $\mathrm{Na}^{+}$ions or the sulfate ions in the hydrolysate appears to have a positive effect on the isomerization, which should be addressed in further studies.

The concentrations of by-products from acid-catalyzed pretreatment of lignocellulose changed during isomerization. For example, the following concentration changes occurred using nitrogen atmosphere, $\mathrm{NaOH}$ neutralization, and $m_{\text {catalyst }} / m_{\text {glucose }}=0.21$ with the conditions listed in Figure 9: Hydroxymethylfurfural ( $910 \mathrm{mg} / \mathrm{L}$ decreased to $710 \mathrm{mg} / \mathrm{L})$, furfural $(230 \mathrm{mg} / \mathrm{L}$ decreased to $50 \mathrm{mg} / \mathrm{L}$ ), levulinic acid (50 mg/L increased to $610 \mathrm{mg} / \mathrm{L}$ ), formic acid (30 mg/L increased to $260 \mathrm{mg} / \mathrm{L}$ ), and acetic acid (30 mg/L increased to $160 \mathrm{mg} / \mathrm{L}$ ). Thus, considerable amounts of organic acids are formed during the isomerization step of biomass-derived hydrolysate, whereas hydroxymethxylfurfural and furfural could be partly converted or adsorb on the catalyst surface.

By neutralizing the hydrolysate before the isomerization step, it was possible to reduce the ratio of glucose conversions to by-products drastically. Using a $\mathrm{pH}$-acidic hydrolysate, $60-80 \mathrm{wt} . \%$ of glucose was converted while maximal 15 wt.\% fructose was formed (see Figure 8). On the other hand, after prior neutralization, the glucose conversion was reduced to $32 \mathrm{wt} . \%$ and a fructose yield of $16 \mathrm{wt} . \%$ was achieved (see Figure 9). The previous neutralization presumably prevents acid-catalyzed side reactions of the glucose, which take place during the isomerization step under acidic conditions (e.g., fragmentation reactions). When the mentioned isomerization results of neutralized lignocellulose hydrolysate are compared with glucose standard solutions, a higher fructose yield was obtained with the glucose standard solution under the same reaction conditions (23 wt.\% fructose yield at $41 \mathrm{wt} . \%$ glucose conversion, see Figure 3). Further studies should show if these differences are due to deactivation of the catalyst using the neutralized hydrolysate. For example, the role of (1) by-products 
from acid-catalyzed pretreatment of lignocellulose (other sugars, furfural, hydroxymethylfurfural, organic acids, high-molecular-weight humins) as well as (2) salts from pretreatment catalyst and neutralization agent should be investigated. In addition, the recovery and regeneration of hydrotalcite catalyst after isomerization of hydrolysate from lignocellulose pretreatment should be addressed.

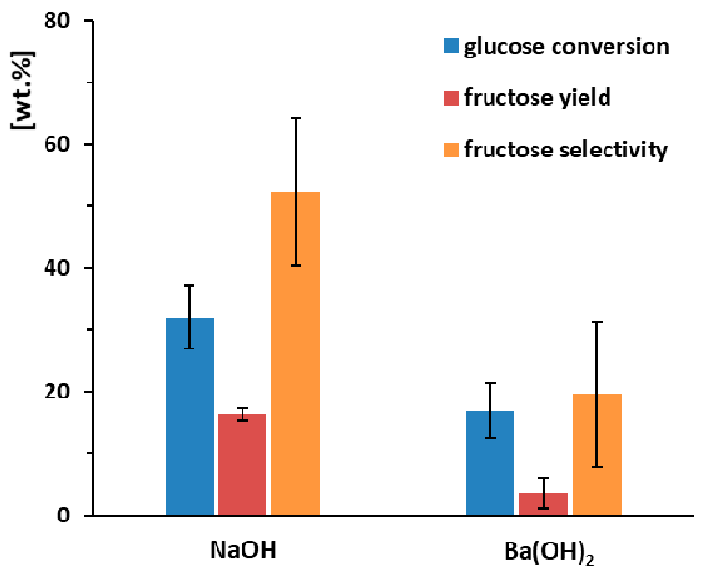

(a)

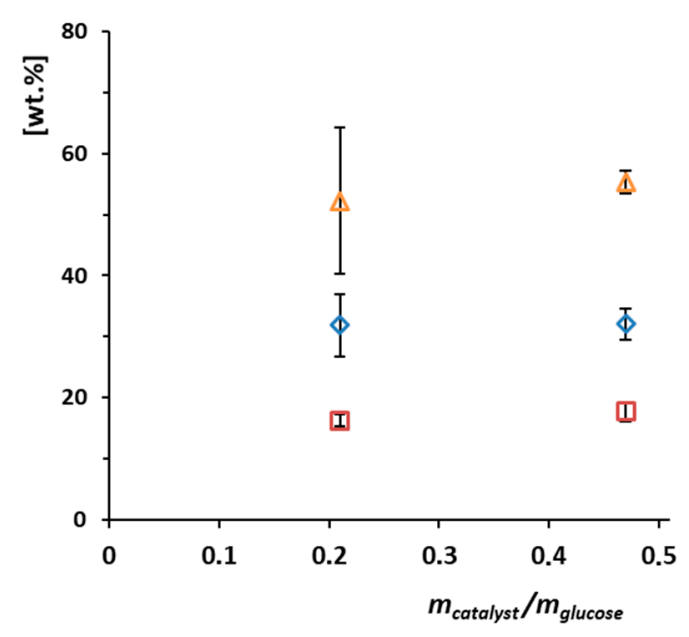

(b)

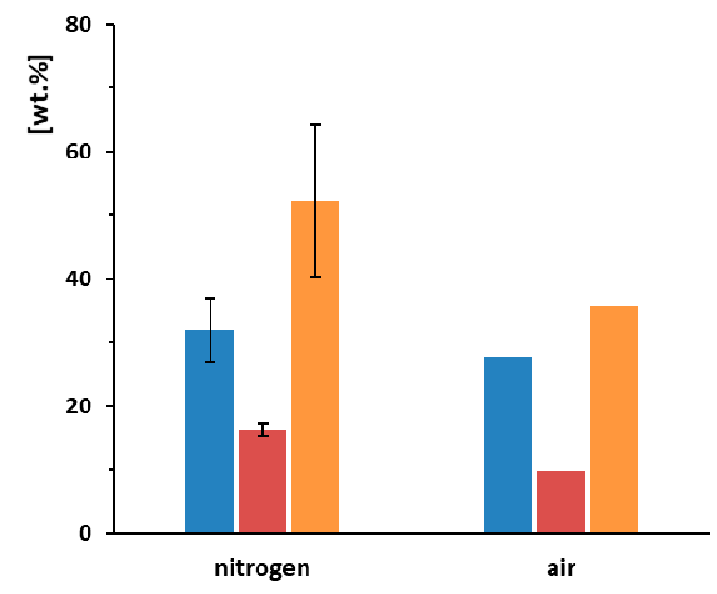

(c)

Figure 9. Glucose conversions and fructose yields of the neutralized hydrolysate from lignocellulose with variation of (a) the neutralizing agent, (b) mass ratio of calcinated hydrotalcite catalyst to glucose, and (c) gas atmosphere; pretreatment parameters: spruce wood, $T=200{ }^{\circ} \mathrm{C}, 0.05 \mathrm{~mol} / \mathrm{L} \mathrm{H}_{2} \mathrm{SO}_{4}$; constant isomerization parameters: $c_{\text {glucose }}=2.1 \mathrm{~g} / \mathrm{L}, \mathrm{pH} \approx 7, T=100^{\circ} \mathrm{C}, t=40 \mathrm{~min}$; parameters (unless otherwise stated): neutralization with $\mathrm{NaOH}$, nitrogen atmosphere, $m_{\text {catalyst }} / m_{\text {glucose }}=0.21$.

\section{Conclusions}

Parameter studies with glucose solutions under $\mathrm{pH}$-neutral conditions showed the best isomerization results ( $25 \mathrm{wt}$. \% fructose yield, $38 \mathrm{wt} . \%$ glucose conversion) at a mass ratio of hydrotalcite to glucose of 0.2 at $90^{\circ} \mathrm{C}$ for a 60 -min reaction time. The carbon balance suggests that side products are more likely to be water insoluble.

Under acidic $\mathrm{pH}$ conditions, the hydrotalcite loses its activity for isomerization. The hydroxides in the solid structure are neutralized by hydronium ions in solution. Thereby, the metal cations become partially water soluble too and the morphology of the catalyst is altered. Consequently, it is unavoidable to neutralize the acidic hydrolysate before the isomerization step with an inexpensive base. During neutralization, almost all organic compounds stay in the liquid state. As a neutralizing agent, $\mathrm{NaOH}$ is 
preferred over $\mathrm{Ba}(\mathrm{OH})_{2}$, since better fructose yields were achieved with $\mathrm{NaOH}$ (16 wt.\% fructose yield, 32 wt. $\%$ glucose conversion).

The isomerization of glucose-containing hydrolysates to fructose is a key step in the process from lignocellulosic biomass to the platform chemical HMF. The catalytic system should be better understood, especially side reactions that occur. If the yields of side products are known, the carbon balance can be improved. Besides studies of the catalytic system with pure model compounds, the application to real biomass-derived samples like hydrolysates should be enhanced.

Author Contributions: D.S., A.K. (Andreas Klier), S.W. and M.Z. designed and performed the experiments as well as analyzed the data. D.S., S.W., A.K. (Andrea Kruse) and J.S. wrote the article. All authors have read and agreed to the published version of the manuscript.

Funding: This work was financially supported by the German Federal Ministry of Food, Agriculture and Consumer Protection (FNR project number 22027811) based on a decision of the German Bundestag. We acknowledge support by Deutsche Forschungsgemeinschaft and Open Access Publishing Fund of Karlsruhe Institute of Technology.

Acknowledgments: We thank Ines Budei for her experimental work. Matthias Pagel and Thomas Tietz built the pretreatment reactor. We thank Sonja Habicht and Armin Lautenbach for HPLC sugar analysis, Manuel Gentzen for XRD measurement, Hermann Köhler for ICP-OES and Wilhelm Habicht for SEM measurements. We acknowledge Nicolaus Dahmen for project supervision.

Conflicts of Interest: The authors declare no conflict of interest. The founding sponsors had no role in the design of the study; in the collection, analyses, or interpretation of data; in the writing of the manuscript, and in the decision to publish the results.

\section{References}

1. Steinbach, D.; Kruse, A.; Sauer, J. Pretreatment technologies of lignocellulosic biomass in water in view of furfural and 5-hydroxymethylfurfural production-A review. Biomass Convers. Biorefinery 2017, 7, 247-274. [CrossRef]

2. van Putten, R.J.; van der Waal, J.C.; de Jong, E.; Rasrendra, C.B.; Heeres, H.J.; de Vries, J.G. Hydroxymethylfurfural, a versatile platform chemical made from renewable resources. Chem. Rev. 2013, 113, 1499-1597. [CrossRef]

3. Steinbach, D.; Kruse, A.; Sauer, J.; Vetter, P. Sucrose Is a Promising Feedstock for the Synthesis of the Platform Chemical Hydroxymethylfurfural. Energies 2018, 11, 645. [CrossRef]

4. Bhosale, S.H.; Rao, M.B.; Deshpande, V.V. Molecular and industrial aspects of glucose isomerase. Microbiol. Rev. 1996, 60, 280. [CrossRef]

5. Tewari, Y.B. Thermodynamics of industrially-important, enzyme-catalyzed reactions. Appl. Biochem. Biotech. 1990, 23, 187-203. [CrossRef]

6. Roman-Leshkov, Y.; Moliner, M.; Labinger, J.A.; Davis, M.E. Mechanism of Glucose Isomerization Using a Solid Lewis Acid Catalyst in Water. Angew. Chem. Int. Edit. 2010, 49, 8954-8957. [CrossRef]

7. Bermejo-Deval, R.; Assary, R.S.; Nikolla, E.; Moliner, M.; Román-Leshkov, Y.; Hwang, S.-J.; Palsdottir, A.; Silverman, D.; Lobo, R.F.; Curtiss, L.A.; et al. Metalloenzyme-like catalyzed isomerizations of sugars by Lewis acid zeolites. Proc. Natl. Acad. Sci. USA 2012, 109, 9727-9732. [CrossRef]

8. Allen, K.N.; Lavie, A.; Farber, G.K.; Glasfeld, A.; Petsko, G.A.; Ringe, D. Isotopic Exchange plus Substrate and Inhibition Kinetics of D-Xylose Isomerase Do Not Support a Proton-Transfer Mechanism. Biochemistry 1994, 33, 1481-1487. [CrossRef]

9. Kovalevsky, A.Y.; Hanson, L.; Fisher, S.Z.; Mustyakimov, M.; Mason, S.A.; Trevor Forsyth, V.; Blakeley, M.P.; Keen, D.A.; Wagner, T.; Carrell, H.L.; et al. Metal Ion Roles and the Movement of Hydrogen during Reaction Catalyzed by D-Xylose Isomerase: A Joint X-Ray and Neutron Diffraction Study. Structure 2010, 18, 688-699. [CrossRef]

10. Usuki, C.; Kimura, Y.; Adachi, S. Isomerization of Hexoses in Subcritical Water. Food Sci. Technol. Res. 2007, 13, 205-209. [CrossRef]

11. Delidovich, I.; Palkovits, R. Catalytic Isomerization of Biomass-Derived Aldoses: A Review. Chemsuschem 2016, 9, 547-561. [CrossRef]

12. Li, B.; Li, L.; Zhang, Q.; Weng, W.; Wan, H. Attapulgite as natural catalyst for glucose isomerization to fructose in water. Catal Commun. 2017, 99, 20-24. [CrossRef] 
13. Marianou, A.A.; Michailof, C.M.; Pineda, A.; Iliopoulou, E.F.; Triantafyllidis, K.S.; Lappas, A.A. Glucose to Fructose Isomerization in Aqueous Media over Homogeneous and Heterogeneous Catalysts. Chemcatchem 2016, 8, 1100-1110. [CrossRef]

14. Cantrell, D.G.; Gillie, L.J.; Lee, A.F.; Wilson, K. Structure-reactivity correlations in MgAl hydrotalcite catalysts for biodiesel synthesis. Appl. Catal. A Gen. 2005, 287, 183-190. [CrossRef]

15. Lecomte, J.; Finiels, A.; Moreau, C. Kinetic study of the isomerization of glucose into fructose in the presence of anion-modified hydrotalcites. Starch-Starke 2002, 54, 75-79. [CrossRef]

16. Delidovich, I.; Palkovits, R. Structure-performance correlations of Mg-Al hydrotalcite catalysts for the isomerization of glucose into fructose. J. Catal. 2015, 327, 1-9. [CrossRef]

17. Yu, S.; Kim, E.; Park, S.; Song, I.K.; Jung, J.C. Isomerization of glucose into fructose over Mg-Al hydrotalcite catalysts. Catal. Commun. 2012, 29, 63-67. [CrossRef]

18. Delidovich, I.; Palkovits, R. Catalytic activity and stability of hydrophobic Mg-Al hydrotalcites in the continuous aqueous-phase isomerization of glucose into fructose. Catal. Sci. Technol. 2014, 4, 4322-4329. [CrossRef]

19. Moreau, C.; Durand, R.; Roux, A.; Tichit, D. Isomerization of glucose into fructose in the presence of cation-exchanged zeolites and hydrotalcites. Appl. Catal. A Gen. 2000, 193, 257-264. [CrossRef]

20. Weisgerber, L.; Palkovits, S.; Palkovits, R. Development of a reactor setup for continuous dehydration of carbohydrates. Chem.-Ing-Tech. 2013, 85, 512-515. [CrossRef]

21. Souzanchi, S.; Nazari, L.; Rao, K.T.V.; Yuan, Z.; Tan, Z.; Xu, C. Catalytic isomerization of glucose to fructose using heterogeneous solid Base catalysts in a continuous-flow tubular reactor: Catalyst screening study. Catal. Today 2019, 319, 76-83. [CrossRef]

22. Yabushita, M.; Shibayama, N.; Nakajima, K.; Fukuoka, A. Selective Glucose-to-Fructose Isomerization in Ethanol Catalyzed by Hydrotalcites. ACS Catal. 2019, 9, 2101-2109. [CrossRef]

23. Lee, G.; Kang, J.Y.; Yan, N.; Suh, Y.-W.; Jung, J.C. Simple preparation method for Mg-Al hydrotalcites as base catalysts. J. Mol. Catal. A Chem. 2016, 423, 347-355. [CrossRef]

24. Kang, J.; Lee, G.; Suh, Y.-W.; Jung, J. Effect of Mg/Al Atomic Ratio of Mg-Al Hydrotalcites on Their Catalytic Properties for the Isomerization of Glucose to Fructose. J. Nanosci. Nanotechnol. 2017, 17, 8242-8247. [CrossRef]

25. Park, S.; Kwon, D.; Kang, J.Y.; Jung, J.C. Influence of the preparation method on the catalytic activity of MgAl hydrotalcites as solid base catalysts. Green Energy Environ. 2019, 4, 287-292. [CrossRef]

26. Murzin, D.Y.; Murzina, E.V.; Aho, A.; Kazakova, M.A.; Selyutin, A.G.; Kubicka, D.; Kuznetsov, V.L.; Simakova, I.L. Aldose to ketose interconversion: Galactose and arabinose isomerization over heterogeneous catalysts. Catal. Sci. Technol. 2017, 7, 5321-5331. [CrossRef]

27. Upare, P.P.; Chamas, A.; Lee, J.H.; Kim, J.C.; Kwak, S.K.; Hwang, Y.K.; Hwang, D.W. Highly Efficient Hydrotalcite/1-Butanol Catalytic System for the Production of the High-Yield Fructose Crystal from Glucose. ACS Catal. 2020, 10, 1388-1396. [CrossRef]

28. Antal, M.J.; Mok, W.S.L.; Richards, G.N. Mechanism of formation of 5-(hydroxymethyl)-2-furaldehyde from d-fructose and sucrose. Carbohydr. Res. 1990, 199, 91-109. [CrossRef]

29. Asghari, F.S.; Yoshida, H. Acid-catalyzed production of 5-hydroxymethyl furfural from D-fructose in subcritical water. Ind Eng. Chem. Res. 2006, 45, 2163-2173. [CrossRef]

30. Świątek, K.; Gaag, S.; Klier, A.; Kruse, A.; Sauer, J.; Steinbach, D. Acid Hydrolysis of Lignocellulosic Biomass: Sugars and Furfurals Formation. Catalysts 2020, 10, 437. [CrossRef]

31. Xie, W.; Peng, H.; Chen, L. Calcined Mg-Al hydrotalcites as solid base catalysts for methanolysis of soybean oil. J. Mol. Catal. A Chem. 2006, 246, 24-32. [CrossRef]

32. Souza, R.O.L.; Fabiano, D.P.; Feche, C.; Rataboul, F.; Cardoso, D.; Essayem, N. Glucose-fructose isomerisation promoted by basic hybrid catalysts. Catal. Today 2012, 195, 114-119. [CrossRef]

33. Wiyantoko, B.; Kurniawati, P.; Purbaningtias, T.E.; Fatimah, I. Synthesis and Characterization of Hydrotalcite at Different Mg/Al Molar Ratios. Procedia Chem. 2015, 17, 21-26. [CrossRef]

34. Hernandez-Moreno, M.J.; Ulibarri, M.A.; Rendon, J.L.; Serna, C.J. IR characteristics of hydrotalcite-like compounds. Phys. Chem. Miner. 1985, 12, 34-38. [CrossRef]

35. Frost, R.L.; Scholz, R.; López, A.; Theiss, F.L. Vibrational spectroscopic study of the natural layered double hydroxide manasseite now defined as hydrotalcite-2H-Mg6Al2(OH)16[CO3]-4H2O. Spectrochim. Acta Part A Mol. Biomol. Spectrosc. 2014, 118, 187-191. [CrossRef] 
36. Cavani, F.; Trifirò, F.; Vaccari, A. Hydrotalcite-type anionic clays: Preparation, properties and applications. Catal. Today 1991, 11, 173-301. [CrossRef]

37. Pérez-Ramírez, J.; Abelló, S.; van der Pers, N.M. Influence of the Divalent Cation on the Thermal Activation and Reconstruction of Hydrotalcite-like Compounds. J. Phys. Chem. C 2007, 111, 3642-3650. [CrossRef]

38. Pérez-Ramírez, J.; Abelló, S.; van der Pers, N.M. Memory Effect of Activated Mg-Al Hydrotalcite: In Situ XRD Studies during Decomposition and Gas-Phase Reconstruction. Chem. A Eur. J. 2007, 13, 870-878. [CrossRef]

39. Bageri, B.S.; Mahmoud, M.A.; Shawabkeh, R.A.; Abdulraheem, A. Evaluation of Barium Sulfate (Barite) Solubility Using Different Chelating Agents at a High Temperature. J. Pet. Sci. Technol. 2017, 7, 42-56. [CrossRef]

(C) 2020 by the authors. Licensee MDPI, Basel, Switzerland. This article is an open access article distributed under the terms and conditions of the Creative Commons Attribution (CC BY) license (http://creativecommons.org/licenses/by/4.0/). 